\title{
Keefektifan Setting TPS dalam Pendekatan Discovery Learning dan Problem- Based Learning pada Pembelajaran Materi Lingkaran SMP
}

\author{
Rahmi Hidayati \\ SMK Kesehatan Borneo Lestari. Jl Kelapa Sawit No. 8 Bumi Berkat Banjar Baru, 70732, Indonesia \\ Email: rahmihidayati.pmatc@gmail.com \\ Received: 19 July 2016; Revised:5 May 2017; Accepted: 8 May 2017
}

\begin{abstract}
Abstrak
Penelitian ini bertujuan untuk mendeskripsikan keefektifan setting TPS dalam pendekatan discovery learning dan problem-based learning terhadap prestasi belajar, kemampuan komunikasi matematis, dan kemampuan interpersonal siswa. Jenis penelitian ini adalah quasi-experimental dengan pretest-posttest nonequivalent group design. Sampel penelitian dipilih secara acak dari delapan kelas yang ada, terpilih dua kelas. Instrumen yang digunakan adalah tes prestasi belajar, tes kemampuan komunikasi matematis, dan angket kemampuan interpersonal. Untuk menguji keefektifan setting TPS dalam pendekatan discovery learning dan problem-based learning data dianalisis menggunakan uji one sample t-test. Untuk menguji perbedaan keefektifan, data dianalisis menggunakan MANOVA. Hasil penelitian menunjukkan bahwa setting TPS dalam pendekatan discovery learning dan problem based learning efektif terhadap prestasi belajar, kemampuan komunikasi matematis, dan kemampuan interpersonal siswa. Tidak terdapat perbedaan keefektifan setting TPS dalam pendekatan discovery learning dengan problem-based learning ditinjau dari aspek prestasi belajar, kemampuan komunikasi matematis, dan kemampuan interpersonal siswa.
\end{abstract}

Kata Kunci: setting TPS, pendekatan discovery learning, pendekatan problem-based learning, prestasi belajar, kemampuan komunikasi matematis, kemampuan interpersonal

\section{The Effectiveness of Setting Think Pair Share in Discovery Learning Approach and Problem-Based Learning in Circle of Junior High School Students}

\begin{abstract}
The purpose of this study was to describe the effectiveness of setting Think Pair Share (TPS) in the approach to discovery learning and problem-based learning in terms of student achievement, mathematical communication skills, and interpersonal skills of the student. This study was a quasiexperimental study using the pretest-posttest nonequivalent group design. The research population comprised all Year VIII students of SMP Negeri 1 Yogyakarta. The research sample was randomly selected from eight classes, two classes were elected. The instrument used in this study is the learning achievement test, a test of mathematical communication skills, and interpersonal skills student questionnaires. To test the effectiveness of setting Think Pair Share (TPS) in the approach to discovery learning and problem-based learning, the one sample t-test was carried out. Then, to investigate the difference in effectiveness between the setting Think Pair Share (TPS) in the approach to discovery learning and problem-based learning, the Multivariate Analysis of Variance (MANOVA) was carried out. The research findings indicate that the setting TPS discovery approach to learning and problembased approach to learning $(P B L)$ is effective in terms of learning achievement, mathematical communication skills, and interpersonal skills of the students. No difference in effectiveness between setting TPS discovery approach to learning and problem-based learning $(P B L)$ in terms of learning achievement, mathematical communication skills, and interpersonal skills of the students.
\end{abstract}

Keywords: TPS setting in discovery learning approach, in problem-based learning, academic achievement, mathematical communication skills, and interpersonal skills of the student

How to Cite: Hidayati, R. (2017). Keefektifan setting TPS dalam pendekatan discovery learning dan problembased learning pada pembelajaran materi lingkaran SMP. Jurnal Riset Pendidikan Matematika, 4(1), 78-86. doi:http://dx.doi.org/10.21831/jrpm.v4i1.9451

Permalink/DOI: http://dx.doi.org/10.21831/jrpm.v4i1.9451 


\section{Jurnal Riset Pendidikan Matematika, 4 (1), 2017 - 79}

Rahmi Hidayati

\section{PENDAHULUAN}

Prestasi belajar siswa diperoleh setelah proses pembelajaran dilakukan dan nilainya dapat diketahui dengan memberikan seperangkat alat evaluasi berupa tes. Menurut Good (Phye, 1997, p. 4), prestasi didefinisikan sebagai (a) pencapaian atau keahlian dalam keterampilan dan pengetahuan, (b) kemajuan di sekolah. Lebih lanjut diungkapkan bahwa prestasi akademik didefinisikan sebagai pengetahuan yang diperoleh atau keterampilan yang dikembangkan pada mata pelajaran di sekolah, yang biasanya didesain dengan skor tes atau dengan pemberian tanda yang dinilai oleh guru.

Fakta lapangan menunjukan bahwa prestasi belajar matematika masih cenderung kurang. Hal tersebut ditunjukan dengan nilai ulangan matematika tahun ajaran 2014-2015 terhadap penguasaan materi soal mengenai menyelesaikan masalah yang berkaitan dengan unsur-unsur/bagian-bagian lingkaran atau hubungan dua lingkaran. Diperoleh persentase ketuntasan siswa kelas VIII pada materi lingkaran tahun ajaran 2014/2015 sebesar 69,14 dari 256 siswa.

Masalah prestasi belajar siswa diindikasikan karena kemampuan komunikasi dan interpersonal siswa yang belum terbangun dengan baik. Daniyati \& Sugiman (2015) mengemukakan bahwa proses pembelajaran yang dilaksanakan di SMP di Kabupaten Purworejo masih berlangsung satu arah di mana siswa hanya mendengarkan penjelasan guru sehingga membatasi interaksi siswa dalam pembelajaran dan menghambat perkembangan kemampuan interpersonal siswa. Dengan demikian maka siswa jarang sekali berdiskusi sehingga kemampuan interpersonal tidak berkembang dengan baik.

Kemampuan komunikasi dan iterpersonal dianggap merupakan suatu hal penting yang harus dikembangkan dalam proses pembelajaran. Hal tersebut nempak jelas pada salah satu poin di peraturan menteri. Poin tersebut adalah menenkankan agar peserta didik mampu mengkomunikasikan gagasan dengan simbol, diagram atau media lain untuk memperjelas keadaan atau masalah, (5) Memiliki sikap menghargai kegunaan matematika dalam kehidupan yaitu memiliki rasa ingin tahu, perhatian, dan minat dalam mempelajari matematika, serta sikap ulet dan percaya diri dalam pemecahan masalah (Menteri Pendidikan Nasional, 2006).

Komunikasi dalam pembelajaran matematika merupakan hal yang sangat penting, karena matematika memiliki bahasa tersendiri yang berupa lambang-lambang atau simbol-simbol dan angka. Hal ini senada dengan pendapat Masykur \& Fathani (2009, p. 45) yang menyatakan bahwa bahasa merupakan suatu sistem yang terdiri dari lambang-lambang atau simbolsimbol, kata-kata, dan kalimat-kalimat yang disusun menurut aturan tertentu dan digunakan sekelompok orang untuk berkomunikasi.

Menurut Van de Walle (2007, p. 4) mengatakan bahwa komunikasi merupakan standar pokok yang memiliki arti penting dalam berbicara, menulis, menggambarkan, dan menjelaskan ide-ide matematika Komunikasi tidak dapat dipungkuri merupakan bagian penting dalam proses belajar dan mengajar matematika. Komunikasi dapat digunakan oleh siswa untuk berbagai ide atau gagasan sehingga diperoleh suatu pemahaman yang benar dalam memecahkan masalah

LACOE (Mahmudi, 2009, p. 3) menyatakan bentuk komunikasi matematis (1) merefleksi dan mengklarifikasi pemikiran tentang ide-ide matematika, (2) menghubungkan bahasa seharihari dengan bahasa matematika yang menggunakan simbol-simbol, (3) menggunakan keterampilan membaca, mendengarkan, menginterpretasikan, dan mengevaluasi ide-ide matematika, dan (4) menggunakan ide-ide matematika untuk membuat dugaan (conjecture) dan membuat argumen yang meyakinkan. Ontario Ministry of Education (2005, p. 16) memberikan gambaran yang sama mengenai komunikasi yaitu sebagai proses mengekspresikan ide-ide matematika dan pemahaman secara lisan, visual, dan secara tertulis, yaitu menggunakan angka, simbol, gambar, grafik, diagram, dan kata-kata.

Dengan demikian dapat disimpulkan bahwa matematika memiliki cara tersendiri dalam berkomunikasi yang sering disebut dengan komunikasi matematis. Dalam penelitian ini kemampuan komunikasi matematis meliputi: (1) Kemampuan merepresentasikan apa yang diketahui dan ditanyakan, (2) Kemampuan dalam mengubah kalimat sehari-hari ke dalam kalimat matematika dengan menggunakan angka, katakata, simbol, gambar, grafik dan diagram dengan tepat terhadap suatu permasalahan, (3) Kemampuan dalam meruntutkan penyelesaikan permasalahan, (4) Kemampuan dalam memberikan alasan atau kesimpulan secara sistematis terhadap akhir dari penyelesaian permasalahan.

Fenomena yang diperoleh dari lapangan menunjukkan bahwa selama proses pembelajaran siswa masih kurang aktif untuk meng- 
komunikasikan ide-ide yang mereka miliki. Pada saat siswa diberikan soal untuk diselesaikan, masih ada siswa yang kurang lengkap dalam menuliskan proses pengerjaannya. Hal ini dapat dilihat dari penyelesaian soal ulangan yang telah dikerjakan oleh siswa. Salah satu soal yang diberikan adalah suatu relasi dinyatakan dengan himpunan pasangan berurutan berikut $\{(-2,-1),(-2,1),(-1,3),(0,2),(1,4),(1,5)\}$ (a) tentukan domain, dan kodomainnya; (b) nyatakan relasi tersebut ke dalam diagram panah; (c) gambarlah relasi tersebut dalam bentuk diagram cartesius. Hasil penyelesaian menunjukkan masih ada siswa yang salah dalam membuat diagram cartesius dan diagram panah. Padahal sebelumnya siswa sudah diajarkan cara membuat diagram panah dan diagram cartesius.

Selain kominikasi, kemampuan interpersonal merupakan kemampuan yang harus berkembang dengan baik. Banyak orang yang tidak menyadari bahwa kemampuan interpersonal merupakan hal penting untuk dapat berhubungan dengan orang lain Kemampuan interpersonal yang baik diperlukan dalam kehidupan pribadi, lingkungan pekerjaan, bermasyarakat, bahkan dibutuhkan oleh siswa dalam berinteraksi di lingkungan sekolah. Kemampuan interpersonal pada umunya digunakan saat berhadapan langsung dengan orang lain.

Interpersonal skills merupakan keterampilan berinteraksi yang berkaitan dalam bersosialisasi. Hayes (2003, p. 3) mengatakan bahwa keterampilan interpersonal adalah perilaku yang diarahkan pada tujuan tertentu yang digunakan dalam interaksi tatap muka, hal itulah yang efektif dalam mewujudkan keadaaan yang diinginkan. Menurut Hayes (1991, p. 5) kemampuan interpersonal efektif dalam mewujudkan keadaan yang diinginkan dalam konteks ini yaitu efektif dalam mewujudkan keberhasilan pembelajaran. Dalam kegiatan pembelajaran, terjadi interaksi antara guru dengan siswa, atau antara siswa dengan siswa yang lain. Interaksi tersebut dapat membantu perkembangan siswa, salah satunya perkembangan kognitif. Kemampuan individu dalam berinteraksi sosial sangat diperlukan dalam proses belajar. Dengan demikian kemampuan interpersonal seseorang memegang peranan yang cukup penting karena dengan kemampuan ini, siswa akan dapat bekerjasama dengan siswa lain dalam mengembangkan pemahaman yang dimiliki.

Kemampuan interpersonal berperan penting dalam pembelajaran matematika di sekolah. Siswa perlu lebih banyak berinteraksi dengan teman yang dianggap lebih pandai atau kepada guru untuk meminta bantuan saat mengalami kesulitan dalam menyelesaikan suatu permasalahan matematika. Dengan demikian, kemampuan interpersonal akan memudahkan siswa dalam mengikuti kegiatan pembelajaran. Interaksi dalam kegiatan belajar dapat berupa tanya jawab dengan guru atau berdiskusi dengan teman.

Dalam konteks pembelajaran di kelas, Gillies (2003, p. 38) mengungkapkan komponen kemampuan interpersonal meliputi (a) actively listening to each other (aktif mendengarkan satu sama lain), (b) stating ideas freely (menyatakan ide dengan bebas), (c) accepting responsibility for one's behaviors (menerima tanggung jawab atas perilaku seseorang), dan (d) providing concructivism criticsm (memberi kritik yang membangun). Adapun komponen kemampuan interpersonal siswa dalam penelitian ini adalah: (1) toleran/empati terhadap orang lain; (2) bertanggung jawab; (3) berkomunikasi; (4) kerja sama, sehingga dapat memperoleh hasil terbaik dan mencapai tujuan dalam pembelajaran matematika.

Memperhatikan permasalahan yang terjadi, peneliti berpendapat diperlukan adanya terobosan dalam pembelajaran yang diharapkan mampu meningkatkan prestasi belajar, mengembangkan kemampuan komunikasi matematis, dan kemampuan interpersonal siswa. Oleh karena itu, guru dituntut untuk memahami dan mampu menerapkan berbagai metode pembelajaran serta pendekatan pembelajaran yang "sesuai" dengan kekhasan materi serta karakteristik siswa sehingga guru dapat memfasilitasi kegiatan siswa dalam belajar.

Diperlukan suatu perubahan yang mendasar terutama strategi pembelajaran dan pendekatan dalam pembelajaran matematika dimana awalnya berpusat pada guru (tearcher centered) menjadi pendekatan yang berpusat pada siswa. Banyak terdapat model pembelajaran serta pendekatan pembelajaran yang dapat digunakan dalam pembelajaran matematika. Merupakan tugas guru untuk memilih model serta pendekatan pembelajaran yang sesuai agar tujuan pembelajaran tercapai.

Salah satu model yang memiliki karakter sesuai untuk menyelesaikan berbagai masalah yang terpapar adalah model kooperatif tipe think pair share (TPS). Arends, Prajitno, \& Mulyantini (2008, p. 15) berpendapat bahwa model pembelajaran TPS merupakan cara yang efektif untuk membuat variasi suasana pola 
diskusi di kelas. Hal ini disebabkan karena prosedur yang digunakan dalam model TPS memberi siswa lebih banyak berpikir, untuk merespons dan saling membantu antar sesama siswa. Dalam penerapannya, model TPS memiliki beberapa kelebihan sebagaimana yang diungkapkan oleh Radhakrishna \& Chikthimmah (2012) yaitu (1) membantu mengorganisir siswa dalam memahami materi; (2) siswa menjadi lebih siap pada setiap sesi kelas; (3) waktu yang diperlukan relatif singkat; (4) memberikan kesempatan para siswa untuk saling berdiskusi dengan anggota kelompoknya; dan (5) membantu guru dalam membuat suasana kelas lebih interaktif.

Untuk memaksimalkan proses pembelajaran, maka TPS akan diposisikan sebagai setting mendampingi suatu pendekatan. Terdapat dua pendekatan yang dirasa memiliki keselarasan dengan TPS sehingga dapat membangun proses pembelajaran yaitu discovery learning dan problem based learning.

Pendekatan discovery learning merupakan suatu pendekatan pembelajaran dimana siswa dituntut untuk mampu menemukan suatu konsep dalam belajar. Dengan ini siswa dituntut untuk lebih aktif dalam proses pembelajaran. Menurut Roestiyah NK (2008, p. 20) "Discovery adalah proses mental dimana siswa mampu mengasimilasikan suatu konsep atau prinsip". Proses mental yang dimaksud yaitu: mengamati, mencerna, mengerti, menggolongkan, membuat dugaan, menjelaskan, mengukur, membuat kesimpulan, dan sebagainya. Peran guru dalam pembelajaran berlangsung hanya sebagai pembimbing dan memberikan instruksi. Siswa berperan lebih aktif dalam menemukan konsep sendiri.

Lefrançois (2000, p. 209) berpendapat bahwa pembelajaran discovery adalah pembelajaran yang terjadi ketika siswa tidak disajikan materi pelajaran secara langsung melainkan diminta untuk menemukan sendiri hubungan yang ada antara informasi-informasi yang diberikan. Balım (2009, p. 2) mengutarakan bahwa dalam pembelajaran terjadi oleh penemuan, yang mengutamakan refleksi, berpikir, bereksperimen, dan bereksplorasi. Dengan tujuan penemuan disini dari yang awalnya tidak diketahui menjadi diketahui oleh siswa itu sendiri. Siswa berpartisipasi aktif selama proses pembelajaran berlangsung.

Sagala (2009, p. 197) mengemukakan terdapat lima tahapan yang ditempuh dalam melaksanakan pendekatan inquiry/discovery yakni: (1) perumusan masalah untuk dipecahkan siswa; (2) menetapkan jawaban sementara atau lebih dikenal dengan istilah hipotesis; (3) siswa mencari informasi, data, fakta yang diperlukan untuk menjawab permasalahan/hipotesis; (4) menarik kesimpulan jawaban atau generalisasi; dan (5) mengaplikasikan kesimpulan/generalisasi dalam situasi baru. Metode mengajar yang biasa digunakan guru dalam pendekatan ini antara lain metode diskusi dan pemberian tugas, diskusi untuk memecahkan permasalahan dilakukan oleh sekelompok kecil siswa anatara empat sampai lima orang dengan arahan dan bimbingan guru.

Satu pendekatan lain adalah problem based learning. Pendekatan problem based learning yang merupakan pendekatan yang melibatkan siswa berperan lebih aktif dalam proses pembelajaran. Problem based learning di Indonesia dikenal dengan belajar berbasis masalah. Dimana guru merancang dan memulai kegiatan pembelajaran dengan memberikan masalah kepada siswa. Dengan pendekatan problem based learning memungkinkan siswa untuk melakukan investigasi, memecahkan masalah, dan menghubungkan antara konsep yang satu dengan konsep yang lain.

Menurut Maxwell, Mergendoller, \& Bellisimo (2005, p. 317) bahwa praktek pengajaran dengan pendekatan belajar berbasis masalah mengubah arah interaksi pembelajaran yang berpusat pada guru kepada pembelajaran yang memungkinkan siswa terlibat aktif dalam kegiatan pembelajaran di kelas. Karakteristik dari pendekatan pembelajaran PBL yaitu adanya masalah sebagai awal dari proses belajar mengajar. Masalah yang dirancang berasal dari permasalahan sehari-hari yang menarik untuk disajikan kepada siswa. Kemudian masalah harus disajikan dengan menyesuaikan pada tuntutan kurikulum, terutama standar kompetensi, kompetensi dasar serta kompetensi yang harus dimiliki siswa setelah mempelajari topik bersangkutan.

Berdasarkan uraian masalah yang terpapar tersebut maka penelitian ini bertujuan untuk mendeskripsikan keefektifan pembelajaran setting tps pendekatan discovery learning dengan setting TPS pendekatan problem based learning ditinjau dari aspek prestasi belajar, kemampuan komunikasi matematis, dan kemampuan interpersonal siswa. Diharapkan hasil dari penelitian ini menjadi referensi bagi guru dalam pembelajaran matematika, terutama yang berkaitan dengan pembelajaran setting tps 


\section{Jurnal Riset Pendidikan Matematika, 4 (1), 2017 - 82}

Rahmi Hidayati

pendekatan discovery learning dan problem based learning, dan bagaimana keefektifan kedua pembelajaran tersebut pada ditinjau dari aspek prestasi belajar, kemampuan komunikasi matematis, dan kemampuan interpersonal siswa.

\section{METODE}

Jenis penelitian ini adalah kuantitatif dan menggunakan desain penelitian kuasi eksperimen (eksperimen semu). Penelitian ini dilakukan di SMP Negeri 1 Yogyakarta. Penelitian ini dilaksanakan pada siswa kelas VIII semester 2 tahun pelajaran 2015/2016. Populasi dalam penelitian ini adalah seluruh siswa kelas VIII SMP Negeri 1 Yogyakarta tahun ajaran 2015/2016, terdiri atas 8 kelas. Dengan menggunakan teknik pengundian secara acak dari 8 kelas diperoleh dua kelas yaitu kelas VIII E dipilih sebagai kelompok eksperimen setting tps pendekatan discovery learning sedangkan kelas VIII F sebagai kelompok eksperimen setting tps pendekatan problem based learning.

Data dalam penelitian ini diperoleh dengan pemberian tes prestasi, tes kemampuan komunikasi matematis, dan pengisian angket kemampuan interpersonal siswa. Instrumen yang digunakan adalah instrumen prestasi belajar, kemampuan komunikasi matematis, dan kemampuan interpersonal.

Dari segi validitas isi, instrumen tes dan angket dinyatakan layak berdasar penilaian ahli. Dari segi validitas konstruk, berdasarkan hasil analisis faktor pada angket kemampuan interpersonal siswa. Reliabilitas tes prestasi belajar terdiri atas tes pilihan ganda yaitu 0,709 dan 0,727 dengan Standar Error Measurement (SEM) sebesar 9,808 dan 9,583. Reliabilitas tes kemampuan komunikasi matematis adalah 0,775 dan 0,873 dengan SEM sebesar 1,054 dan 1,021. Reliabilitas tes kemampuan interpersonal 0,805 dengan SEM sebesar 3,887.

Data pretest dan posttest disajikan secara deskriftif dan inferensial. Teknik analisis data dilakukan dengan cara mendeskripsikan data dan menganalisis statistik inferensial terhadap data yang diperoleh. Deskripsi data dilakukan dengan mencari rata-rata, standar deviasi, varians, skor minimal, dan skor maksimal dari data yang diperoleh, baik untuk data sebelum perlakuan, maupun untuk data setelah perlakuan. Untuk menguji apakah setting tps dalam pendekatan discovery learning dan problem based learning efektif ditinjau dari prestasi belajar, kemampuan komunikasi matematis, dan kemampuan interpersonal siswa digunakan uji one sample t-test dengan formula sebagai berikut:

$$
t=\frac{\bar{x}-\mu_{0}}{\frac{S}{\sqrt{n}}}
$$

$\bar{x}$ : Nilai rata-rata sampel

$\mu_{0}$ : nilai rata-rata yang ditetapkan

S : Standar deviasi sampel

$\mathrm{n}$ : banyak anggota sampel

Nilai rata-rata yang ditetapkan $\left(\mu_{0}\right)$ untuk kriteria keefektifan ditinjau dari prestasi belajar, kemampuan komunikasi matematis, dan kemampuan interpersonal siswa berturut-turut adalah 71, 71, dan 68. Pengujian hipotesis menggunakan bantuan SPSS 21 for Windows dengan kriteria keputusan pendekatan pembelajaran dikatakan efektif apabila diperoleh nilai signifikansinya lebih besar atau sama dengan 0,05 .

Sebelum melakukan uji MANOVA, terlebih dahulu dilakukan uji asumsi terhadap data prestasi belajar, kemampuan komunikasi matematis, dan kemampuan interpersonal siswa, yaitu uji normalitas multivariat dan uji homogenitas matriks varians-kovarians, baik untuk data sebelum dan setelah perlakuan. Uji normalitas multivariat dilakukan menggunakan uji jarak Mahalanobis dengan kriteria keputusan bahwa data dikatakan berdistribusi normal jika sekitar 50\% data mempunyai nilai. Uji homogenitas matriks varians-kovarians dilakukan dengan menggunakan uji Box's $M$ dengan kriteria keputusan bahwa data dikatakan homogen jika nilai signifikansi $F$ lebih besar dari 0,05. Untuk data sebelum perlakuan dilakukan uji MANOVA untuk melihat apakah terdapat perbedaan kemampuan awal antara dua kelas sampel ditinjau dari aspek prestasi belajar, kemampuan komunikasi matematis, dan kemampuan interpersonal siswa dengan menggunakan formula sebagai berikut:

$$
T^{2}=\frac{n_{1} n_{2}}{n_{1}+n_{2}}\left(\bar{y}_{1}-\bar{y}_{2}\right)^{\prime} S^{-1}\left(\bar{y}_{1}-\bar{y}_{2}\right)
$$

(Stevens, 2009, p. 148) dengan:

$T^{2}: T^{2}$ Hotelling's

$n_{1}$ : banyak subjek kelompok I

$n_{2}$ :banyak subjek kelompok II

$\bar{y}_{1}$ : vektor rata-rata kelompok I

$\bar{y}_{2}$ : vektor rata-rata kelompok II

$S^{-1}$ : invers matriks kovarians.

Setelah memperoleh nilai $T^{2}$ Hotteling's, selanjutnya nilai tersebut ditransformasikan 
untuk memperoleh nilai distribusi $F$ dengan formula sebagai berikut:

$$
F=\frac{n_{1}+n_{2}-p-1}{\left(n_{1}+n_{2}-2\right) p} T^{2}
$$

Dengan $p$ merupakan banyaknya variabel terikat. Kriteria pengujiannya yakni hipotesis terdapat perbedaan rata-rata kelompok setting tps dalam pendekatan discovery learning dengan kelompok setting tps dalam pendekatan problem based learning ditolak jika nilai signifikansinya lebih kecil dari 0,05. Setelah diketahui bahwa tidak terdapat perbedaan kemampuan awal antara kedua kelas sampel, maka untuk data prestasi belajar, kemampuan komunikasi matematis, dan kemampuan interpersonal siswa setelah perlakuan pun dilakukan uji untuk melihat apakah terdapat perbedaan.

Pengujian perbedaan keefektifan pembelajaran setting tps dalam pendekatan discovery learning dan pembelajaran setting tps dalam pendekatan problem based learning ditinjau dari prestasi belajar, kemampuan komunikasi matematis, dan kemampuan interpersonal siswa menggunakan rumus MANOVA. Setelah diketahui bahwa terdapat perbedaan keefektifan, maka terhadap data tersebut dilakukan uji independent t-test untuk melihat perbandingan setting tps dalam pendekatan discovery learning dengan setting tps dalam pendekatan problem based learning ditinjau dari prestasi belajar, kemampuan komunikasi matematis, dan kemampuan interpersonal siswa, dengan menggunakan formula sebagai berikut:

$$
\begin{aligned}
t= & \frac{\bar{y}_{1}-\bar{y}_{2}}{\sqrt{S^{2}\left(\frac{1}{n_{1}}+\frac{1}{n_{2}}\right)}} \\
& \text { Dengan } S^{2}=\frac{\left(n_{1}-1\right) s_{1}{ }^{2}+\left(n_{2}-1\right) s_{2}{ }^{2}}{n_{1}+n_{2}-2}
\end{aligned}
$$

(Stevens, 2009, p. 147) dengan:

$\bar{y}_{1}$ : nilai rata-rata sampel I

$\bar{y}_{2}$ : nilai rata-rata sampel II

$s_{1}{ }^{2}$ : varians sampel I

$s_{2}{ }^{2}$ : varians sampel II

$n_{1}$ : jumlah subjek kelompok I

$n_{2}$ : jumlah subjek kelompok II

Pengujian hipotesis perbandingan dalam penelitian ini menggunakan bantuan SPSS 21 for Windows dengan kriteria keputusan pembelajaran setting tps dalam pendekatan problem based learning lebih efektif dibandingkan dengan setting tps dalam pendekatan discovery learning.

\section{HASIL DAN PEMBAHASAN}

Data yang dideskripsikan berupa hasil pretest dan posttest prestasi belajar, kemampuan komunikasi matematis, dan hasil angket kemampuan interpersonal siswa yang dikumpulkan sebelum dan sesudah diberi perlakuan serta hasil observasi keterlaksanaan pembelajaran. Data hasil tes prestasi belajar pada kelas TPS+DL dan kelas TPS+PBL dideskripsikan berdasarkan nilai pretest dan posttest.

Tabel 1. Dekskripsi Hasil Pretest dan Postest Prestasi Belajar Kelas TPS+DL dan TPS+PBL

\begin{tabular}{ccccc}
\hline \multirow{2}{*}{ Deskripsi } & \multicolumn{2}{c}{ TPS + DL } & \multicolumn{2}{c}{ TPS + PBL } \\
\cline { 2 - 5 } & Pret & Postt & Pret & Postt \\
\hline Rata-rata & 51,3 & 79,9 & 45,0 & 79,1 \\
Variansi & 178,5 & 66,9 & 157,6 & 64,4 \\
Standar Dev & 13,36 & 8,18 & 12,55 & 8,02 \\
Max Teor & 100 & 100 & 100 & 100 \\
Min Teor & 0 & 0 & 0 & 0 \\
Nilai Max & 75 & 95 & 75 & 95 \\
Nilai Min & 30 & 60 & 25 & 60 \\
\hline
\end{tabular}

Berdasarkan Tabel 1, diperoleh informasi bahwa nilai rata-rata prestasi belajar, baik untuk kelas TPS+DL, maupun kelas TPS+PBL mengalami peningkatan setelah dilakukan treatment. Pada kelas TPS+DL mengalami peningkatan sebesar 28,6 yaitu skor awal 51,3 menjadi 79,9. Sedangkan untuk kelas TPS+PBL mengalami peningkatan sebesar 34,1 denagn rata-rata awal 45,0 menjadi 79,1.

Deskripsi data kemampuan komunikasi matematis, baik untuk kelas TPS+DL, maupun untuk kelas TPS+PBL bisa dilihat pada Tabel 2

Tabel 2. Dekskripsi Hasil Pretest dan Postest Kemampuan Komunikasi Matematis Kelas TPS+DL dan TPS+PBL

\begin{tabular}{ccccc}
\hline \multirow{2}{*}{ Deskripsi } & \multicolumn{2}{c}{ TPS + DL } & \multicolumn{2}{c}{ TPS + PBL } \\
\cline { 2 - 5 } & Pret & Postt & Pret & Postt \\
\hline Rata-rata & 66,0 & 71,4 & 64,6 & 71,5 \\
Variansi & 37,15 & 59,37 & 20,55 & 70,80 \\
Kategori & Rendah & Sedang & Rendah & Rendah \\
Standar Dev & 6,09 & 7,71 & 4,53 & 8.41 \\
Max Teor & 125 & 125 & 125 & 125 \\
Min Teor & 25 & 25 & 25 & 25 \\
Nilai Max & 79 & 85 & 73 & 85 \\
Nilai Min & 56 & 53 & 57 & 53 \\
\hline
\end{tabular}

Berdasarkan Tabel 2, diperoleh informasi bahwa nilai rata-rata kemampuan komunikasi matematis, baik untuk kelas TPS+DL, maupun kelas TPS+PBL mengalami peningkatan setelah dilakukan treatment. Pada kelas TPS+DL mengalami peningkatan sebesar 45,9 yaitu skor awal 32,9 menjadi 78,8. Sedangkan untuk kelas 
TPS+PBL mengalami peningkatan sebesar 49,3 denagn rata-rata awal 30,4 menjadi 79,7.

Deskripsi data kemampuan interpersonal siswa, baik untuk kelas TPS+DL, maupun untuk kelas TPS+PBL bisa dilihat pada Tabel 3

Tabel 3. Dekskripsi Hasil Pretest dan Postest Kemampuan Interpersonal Siswa Kelas TPS+DL dan TPS+PBL

\begin{tabular}{ccccc}
\hline \multirow{2}{*}{ Deskripsi } & \multicolumn{2}{c}{ TPS + DL } & \multicolumn{2}{c}{ TPS + PBL } \\
\cline { 2 - 5 } & Pretest & Posttest & Pretest & Posttest \\
\hline Rata-rata & 32,9 & 78,8 & 30,4 & 79,7 \\
Variansi & 86,78 & 185,21 & 145,88 & 214,43 \\
Standar Dev & 9,32 & 13,6 & 12,08 & 14,64 \\
Max Teor & 100 & 100 & 100 & 100 \\
Min Teor & 0 & 0 & 0 & 0 \\
Nilai Max & 50 & 100 & 75 & 100 \\
Nilai Min & 5,56 & 50 & 11,11 & 50 \\
\hline
\end{tabular}

Berdasarkan Tabel 3, diperoleh informasi bahwa nilai rata-rata kemampuan interpersonal siswa, baik untuk kelas TPS+DL, maupun kelas TPS+PBL mengalami peningkatan setelah dilakukan treatment. Pada kelas eksperimen 1 mengalami peningkatan sebesar 5,5 yaitu skor awal 66,0 kategori rendah menjadi 71,5 dengan kategori sedang. Sedangkan untuk kelas eksperimen 2 mengalami peningkatan sebesar 6,9 denagn rata-rata awal 64,6 kategori rendah menjadi 71,5 dengan kategori sedang.

Berdasarkan analisis yang telah dilakukan, diperoleh rata-rata total keterlaksanaan pembelajaran matematika setting tps dalam pendekatan discovery learning adalah 92,98\% sedangkan rata-rata total keterlaksanaan pembelajaran matematika setting tps dalam pendekatan problem based learning adalah 93,94\%. Dari rerata butir kegiatan pembelajaran yang terlaksana dapat dikatakan bahwa pembelajaran dengan setting tps dalam pendekatan discovery learning dan setting tps dalam pendekatan problem based learning sudah terlaksana dengan baik.

Uji normalitas dan homogenitas data prestasi belajar, kemampuan komunikasi matematis, dan kemampuan interpersonal siswa untuk sebelum dan setelah perlakuan, baik untuk kelas eksperimen 1, maupun untuk kelas eksperimen 2 secara berturut-turut bisa dilihat pada Tabel 4 dan Tabel 5.

Tabel 4. Hasil Uji Normalitas

\begin{tabular}{ccc}
\hline Kelas & $\begin{array}{c}\boldsymbol{d}_{\boldsymbol{i}}^{\mathbf{2}} \text { Sebelum } \\
\text { Perlakuan }\end{array}$ & $\begin{array}{c}\boldsymbol{d}_{\boldsymbol{i}}^{\mathbf{2}} \text { Setelah } \\
\text { Perlakuan }\end{array}$ \\
\hline TPS+DL & $51,43 \%$ & $48,57 \%$ \\
TPS+PBL & $44,12 \%$ & $44,12 \%$ \\
\hline
\end{tabular}

Tabel 4 memperlihatkan bahwa sekitar $50 \%$ data mempunyai nilai $d_{i}^{2}<X_{(3 ; 0,5)}^{2}$. Atau dengan kata lain, data prestasi belajar, data kemampuan komunikasi matematis, dan kemampuan interpersonal siswa untuk sebelum dan setelah perlakuan, baik untuk kelas TPS+DL, maupun untuk kelas TPS+PBL sudah memenuhi asumsi normalitas.

Tabel 5. Hasil Uji Homogenitas

\begin{tabular}{ccc}
\hline & $\begin{array}{c}\text { Sebelum } \\
\text { Perlakuan }\end{array}$ & $\begin{array}{c}\text { Setelah } \\
\text { Perlakuan }\end{array}$ \\
\hline Box's $M$ & 9,870 & 12,458 \\
$F$ & 1,565 & 1,975 \\
Sig. & 0,153 & 0,065 \\
\hline
\end{tabular}

Berdasarkan Tabel 5, diperoleh informasi bahwa nilai signifikansi $F$ lebih besar dari 0,05 atau dengan kata lain, data prestasi belajar, kemampuan komunikasi matematis, matematika, dan kemampuan interpersonal siswa untuk sebelum dan setelah perlakuan sudah memenuhi asumsi homogenitas.

Hasil uji mengenai keefektifan pembelajaran setting tps dalam pendekatan discovery learning dan problem based learning ditinjau dari aspek prestasi belajar, kemampuan komunikasi matematis, dan kemampuan interpersonal siswa dapat dilihat pada Tabel 6 .

Tabel 6. Hasil Uji One Sample t-test

\begin{tabular}{ccccc}
\hline \multirow{2}{*}{ Aspek } & \multicolumn{2}{c}{ TPS+DL } & \multicolumn{2}{c}{ TPS+PBL } \\
\cline { 2 - 5 } & $\mathbf{t}$ & sig & t & sig \\
\hline PB & 6,407 & 0,000 & 5,901 & 0,000 \\
KKM & 3,395 & 0,002 & 3,480 & 0,001 \\
KI & 2,611 & 0,013 & 2,446 & 0,020 \\
\hline
\end{tabular}

Keterangan

PB : Prestasi Belajar

KKM : Kemampuan Komunikasi Matematis

KI : Kemampuan Interpersonal Siswa

Berdasarkan Tabel 6, diperoleh informasi bahwa nilai signifikansi $t$ untuk semua aspek lebih kecil dari 0,05. Artinya, pembelajaran setting TPS dalam pendekatan discovery learning dan pembelajaran setting TPS dalam pendekatan problem based learning efektif ditinjau dari aspek prestasi belajar, kemampuan komunikasi matematis, dan kemampuan interpersonal siswa. Hasil di atas kemudian sejalan dengan kajian teori yang mengungkapkan bahwa kedua pembelajaran tersebut efektif ditinjau dari ketiga aspek yang diukur. Hal ini disebabkan karena pada pembelajaran dengan setting tps siswa aktif dalam berdiskusi menyelesaikan masalah yang terdapat pada LKS.

Pada pembelajaran setting tps dalam pendekatan discovery learning, siswa diberikan 
kesempatan untuk menyelesaikan suatu soal yang bersifat masalah yang terdapat dalam LKS. Siswa diberi waktu untuk menyelesaikannya terlebih dahulu secara individu (think), disini siswa dapat mengembangkan pemahamannya terhadap masalah yang diberikan. Setidaknya pada tahap think ini siswa sudah memiliki permahaman dan jawaban sementara terhadap masalah yang diberikan. Selanjutnya, siswa duduk berpasangan (pair) untuk mendiskusikan masalah yang diberikan, menyatukan pemikiran, menemukan konsep, setelah mendapat jawaban dan kesepakatan maka siswa akan mempresentasikan hasil diskusi mereka ke depan kelas (share). Pada tahap share memungkinkan peningkatan pemahaman siswa karena siswa dapat bertanya atas apa yang tidak dipahaminya kepada teman yang presentasi, bertukar ide dan gagasan.

Pada pembelajaran setting tps dalam pendekatan problem based learning, siswa diberikan kesempatan untuk menyelesaikan suatu soal yang bersifat masalah yang terdapat dalam LKS. Siswa diberi waktu untuk menyelesaikan masalahnya terlebih dahulu secara individu (think), disini siswa dapat mengembangkan pemahamannya terhadap masalah yang diberikan. Setidaknya pada tahap think ini siswa sudah memiliki pemahaman dan jawaban sementara terhadap masalah yang diberikan. Selanjutnya, siswa duduk berpasangan (pair) untuk mendiskusikan masalah yang diberikan, menyatukan pemikiran, setelah mendapat jawaban dan kesepakatan maka siswa akan mempresentasikan hasil diskusi mereka ke depan kelas (share). Pada tahap share memungkinkan peningkatan pemahaman siswa karena siswa dapat bertanya atas apa yang tidak dipahaminya kepada teman yang presentasi, bertukar ide dan gagasan.

Hasil penelitian pun selaras dengan hasil penelitian yang dilakukan oleh Siregar \& Marsigit, (2015, p. 2) bahwa pendekatan discovery learning dan problem based learning efektif ditinjau prestasi belajar, kemampuan komunikasi matematis dan kemampuan interpersonal siswa. Hasil uji mengenai apakah terdapat perbedaan kemampuan awal antara kedua kelas sampel sebelum diberikan perlakuan dan perbedaan keefektifan pembelajaran setting tps dalam pendekatan discovery learning dan problem based learning ditinjau dari prestasi belajar, kemampuan komunikasi matematika, dan kemampuan interpersonal siswa dapat dilihat pada Tabel 7.
Tabel 7. Hasil $T^{2}$ Hotelling Sebelum dan Setelah Perlakuan

\begin{tabular}{ccc}
\hline & F & Sig. \\
\hline Sebelum Perlakuan & 2,316 & 0,084 \\
Setelah Perlakuan & 0,135 & 0,939 \\
\hline
\end{tabular}

Berdasarkan Tabel 7, diperoleh informasi bahwa nilai signifikansi $F$ lebih besar dari 0,05 untuk data sebelum perlakuan dan setelah perlakuan. Artinya, untuk sebelum dan sesudah perlakuan, tidak terdapat perbedaan kemampuan awal antara kelas setting tps dalam pendekatan discovery learning dengan setting tps dalam pendekatan problem based learning ditinjau dari aspek prestasi belajar, kemampuan komunikasi matematis, dan kemampuan interpersonal siswa. Setelah perlakuan, tidak terdapat perbedaan keefektifan pembelajaran setting tps dalam pendekatan discovery learning dengan setting tps dalam pendekatan problem based learning ditinjau dari aspek prestasi belajar, kemampuan komunikasi matematis, dan kemampuan interpersonal siswa.

\section{SIMPULAN}

Pembelajaran setting TPS dalam pendekatan discovery learning dan pembelajaran setting TPS dalam pendekatan problem based learning efektif ditinjau dari aspek prestasi belajar, kemampuan komunikasi matematis, dan kemampuan interpersonal siswa. Pembelajaran setting TPS dalam pendekatan discovery learning dan pembelajaran setting TPS dalam pendekatan problem based learning tidak terdapat perbedaan keefektifan ditinjau dari aspek prestasi belajar, kemampuan komunikasi matematis, dan kemampuan interpersonal siswa.

\section{DAFTAR PUSTAKA}

Arends, R. I., Prajitno, H., \& Mulyantini, S. (2008). Belajar untuk mengajar (Learning to teach), 1 Edisi 9 (7 edition). Yogyakarta: Salemba Humanika .

Balım, A. G. (2009). The effects of discovery learning on students' success and inquiry learning skills. Eurasian Journal of Educational Research Egitim Arastirmalari-Eurasian Journal of Educational Research, 35(35), 1-20. Retrieved from http://www.ejer.com.tr/0DOWNLOAD/p dfler/eng/1177009234.pdf

Daniyati, N. A., \& Sugiman, S. (2015). Hubungan antara kemampuan verbal, kemampuan interpersonal, dan minat 
belajar dengan prestasi belajar matematika. PYTHAGORAS: Jurnal Pendidikan Matematika, 10(1), 50-60. http://doi.org/10.21831/PG.V10I1.9109

Gillies, R. M. (2003). Cooperative learning: Integrating theory and practice. London: SAGE Publications.

Hayes, J. (1991). Interpersonal skills: Goaldirected behaviour at work. New York: Routledge.

Hayes, J. (2003). Interpersonal skills at work. New York: Routledge.

Lefrançois, G. R. (2000). Psychology for teaching: A bear is not a choirboy! Belmont: Wadsworth/Thomson Learning.

Mahmudi, A. (2009). Komunikasi dalam pembelajaran matematika. Jurnal MIPMIPA UNHALU, 8(1), 1412-2318.

Masykur, M., \& Fathani, A. H. (2009). Mathematical intelegence: Cara cerdas melatih otak dan menanggulangi kesulitan belajar. Jogyakarta: AR-Ruzz Media.

Maxwell, N. L., Mergendoller, J. R., \& Bellisimo, Y. (2005). Problem-based learning and high school macroeconomics: A comparative study of instructional methods on JSTOR. The Journal of Economic Education, 36(4), 315-331. Retrieved from https://www.jstor.org/stable/30042670?se $\mathrm{q}=1 \#$ page_scan_tab_contents

Menteri Pendidikan Nasional. Peraturan Menteri Pendidikan Nasional RI nomor 22, tahun 2006, tentang standar isi intuk satuan pendidikan dan menengah, Peraturan Menteri Pendidikan Nasional (2006).

Ontario Ministry of Education. (2005).
Mathematics: The Ontario Curriculum Grades 9 and 10. Toronto: Queen's Printer for Ontario. Retrieved from http://www.edu.gov.on.ca/eng/curriculum /secondary/math910curr.pdf

Phye, G. D. (1997). Handbook of classroom assessment: Learning, achievement, and adjustment. San Diego, CA: Academic Press, Inc.

Radhakrishna, R., \& Chikthimmah, N. (2012). TPS (think, pair and share) as an active learning strategy. NACTA Journal, 56(3), 84-85. Retrieved from https://www.nactateachers.org/images/Se p12_3_TPS_Think_Pair_and_Share_as_a n_Active_Learning_Strategy.pdf

Roestiyah NK. (2008). Strategi belajar mengajar: salah satu unsur pelaksanaan strategi belajar mengajar, teknik penyajian. Jakarta: Rhineka Cipta.

Sagala, S. (2009). Konsep dan makna pembelajaran untuk membantu memecahkan problematika belajar dan mengajar. Bandung: Alfabeta.

Siregar, N. C., \& Marsigit, M. (2015). Pengaruh pendekatan discovery yang menekankan aspek analogi terhadap prestasi belajar, kemampuan penalaran, kecerdasan emosional spiritual. Jurnal Riset Pendidikan Matematika, 2(2), 224. http://doi.org/10.21831/jrpm.v2i2.7336

Stevens, J. P. (2009). Applied multivariate statistics for the social sciences, Fifth Edition. New York: Routledge.

Van de Walle, J. A. (2010). Elementary and middle school mathematics: teaching developmentally. Boston: Pearson /Allyn and Bacon. 